Ann. Biol. anim. Bioch. Biophys., 1975, 15 (2), I31-146.

\title{
INTERACTIONS BETWEEN OVARIAN STEROIDS OR PROGESTAGENS AND LH RELEASE
}

\author{
J. PELLETIER and J. 'THIMONIER \\ Station de Physiologie de la Reproduction, \\ Centre de Recherches de Tours, I. N. R. A., \\ Nousilly, 37380 Monnaic (France)
}

\section{SUMMARY}

There is no doubt today that preovulatory LH surge is related to previous oestrogen secretion in domestic animals. An increase in plasma $I_{7} \beta$-oestradiol precedes LH surge in natural conditions, but the surge can be induced by oestrogen treatment in the anestrous or castrated ewe. Thus, a $50 \mu \mathrm{g}$ injection of oestradiol benzoate induces, in $90 \mathrm{p}$. Ioo of castrated females, a LH peak of the same magnitude but of longer duration (16.30 hours vs I0.30 hours, $\mathrm{P}<0.01$ ) than observed during the estrous cycle. Conversely, although progesterone probably has a positive indirect effect on preovulatory surge, it appears to act mainly as an inhibitor under experimental conditions. No castrated ewes display a LH peak after one progesterone injection $(25 \mathrm{mg})$ or a series of injections; in all cases, further progesterone treatment inlibits the positive effect of $\mathrm{I}_{7}$-oestradiol ( 4 to 8 females per group).

Little is known about the effect of steroids at the hypothalamic level, although it is thought that the positive feedback cffect of oestrogens and the negative feedback effect of progesterone are exerted at this site. The influence of oestrogen is suggested by a 50 p. Ioo decrease in LRF activity at the time of $\mathrm{LH}$ surge, interpreted as a $\mathrm{LRF}$ release. A progesterone effect at the hypothalamic level may be deduced from studies in which progestagens induce a decrease in LRF activity of lactating ewes in the absence of any LH surge. This decrease reaches $\mathrm{I}_{5}$ and $32 \mathrm{p}$. Ioo of the control values in females treated with 20 or $40 \mathrm{mg}$, respectively, of fluorogestone acetate.

A more recent demonstration of the interplay between steroids and hypothalamo-pituitary activity is the variation of pituitary responsiveness to LRF during the estrous cycle. In ewes, an intravenous $\mathrm{LRF}$ injection induces $\mathrm{LH}$ release, which varies according to the stage of the estrous cycle. Mean $\mathrm{LH}$ response after a $25 \mu \mathrm{g} \mathrm{LRF}$ injection is $57,23,18$ or $146 \mathrm{ng} / \mathrm{ml} / \mathrm{s}$ hour when LRF is given on day 4,8 , I 2 or $r 6$, respectively, of the estrous cycle. This L.H response is correlated with the oestrogen/progesterone plasma ratio $(r=-0.97, \mathrm{P}<0.05)$ which appears to regulate LRF effect at the pituitary level.

A relationship between steroids and preovulatory $\mathrm{LH}$ surge was suggested as early as 1934; HoHLWE, showed that oestrogen injection induced ovulation in rats. This "Hohlweg effect " was later found again in the ewe (HAmmond, I945), 
but 25 years more were to elapse before discovery of the physiological bases of these facts in domestic animals. On the other hand, after a period of latency, as soon as circulating hormones could be measured, the problem of steroid-LH release interaction was widely studied. From a fundamental point of view, the relationship between hypothalamus, pituitary and gonads appeared more complex than the simple feedback mechanism first conceived; on the other hand in medical or zootechnical fields, the control of this L/H release appeared to be of utmost importance, namely because progestagens were used to regulate sexual cycles.

Determination of hormone plasma levels, delimitation of the respective roles of oestrogens and progesterone, and the effects of the latter on the hypothalamus and the pituitary have been the main lines of research in endocrinological studies of the periovulatory period.

\section{I. - PREOVULATORY LH RELEASE}

\section{AND CIRCULATING STEROIDS DURING THF, ESTRUS PERIOD}

\section{I. - Steroid and LH variations before ovulation in the ewe}

Hormonal variations occurring at the time of estrus have been studied in greater detail in the ewe than in other domestic animals. At the end of the estrous cycle, three major variations occur involving progestins, oestrogens and pituitary hormones.

Thus, progesterone measured in the ovarian vein from the ovary bearing the corpus luteum decreases by Ioo fold (from I ooo to Io $\mathrm{ng} / \mathrm{ml}$ ) between 48 and 24 hours before estrus when luteolysis occurs (BJERSING et al., I972; MOORE et al., I969). On the contrary, oestrogens (oestradiol-I $7 \beta$ ) increase from some tens of $\mathrm{pg} / \mathrm{ml}$ to more than I ng/ml before estrus (BJERSING et al., I972 ; MOORE et al., I969 ; SCARAMUzzi et al., I970; Cox et al., I97I), then decline rapidly between 6 and I6 hours after onset of estrus (MOORE et al., rg69). Similar variations are observed in the peripheral blood, but they are smaller. Progesterone varies from $2-3 \mathrm{ng} / \mathrm{ml}$ to less than $0.5 \mathrm{ng} / \mathrm{ml}$ (STABENFELDT et al., Ig69 $a$; THORBURN et al., I969), and oestrogens from about $5 \mathrm{pg} / \mathrm{ml}$ to $50 \mathrm{pg} / \mathrm{ml}$ (TERQUI et al., I974) (fig. I).

Plasma LH presents minor variations during the whole cycle up to the onset of estrus (LAND et al., I973). In the majority of cases, LH surge starts between o and Io hours after onset of estrous behavior ; it consists of an increase of the plasma level from I-2 ng/ml to 60-I20 ng/ml (GESCHWIND and DEWEY, I968; NISWENDER et al., Ig68; PELLETIER et al., I968; WHEATIEY and RADFORD, I969). The duration of the surge is IO-I 2 hours (NISWENDER it al., I968; PEILETIER and THIMONIER, I969), and occurs about 26 hours before orulation (WHEATLEY and RADFORD, I969 ; Cumming et al., I97I).

A relationship between the quantity of $\mathrm{LH}$ released and the ovulation rate has not been found in cyclic ewes. However, the interval " onset of estrus-beginning of LH surge " is greater in females showing two ovulations than in those with only one ovulation (ThImonier and PelLETIER, I97I). Similarly, this interval is greater in highly prolific breeds than in breeds of low prolificacy (LAND ct al., I973). 


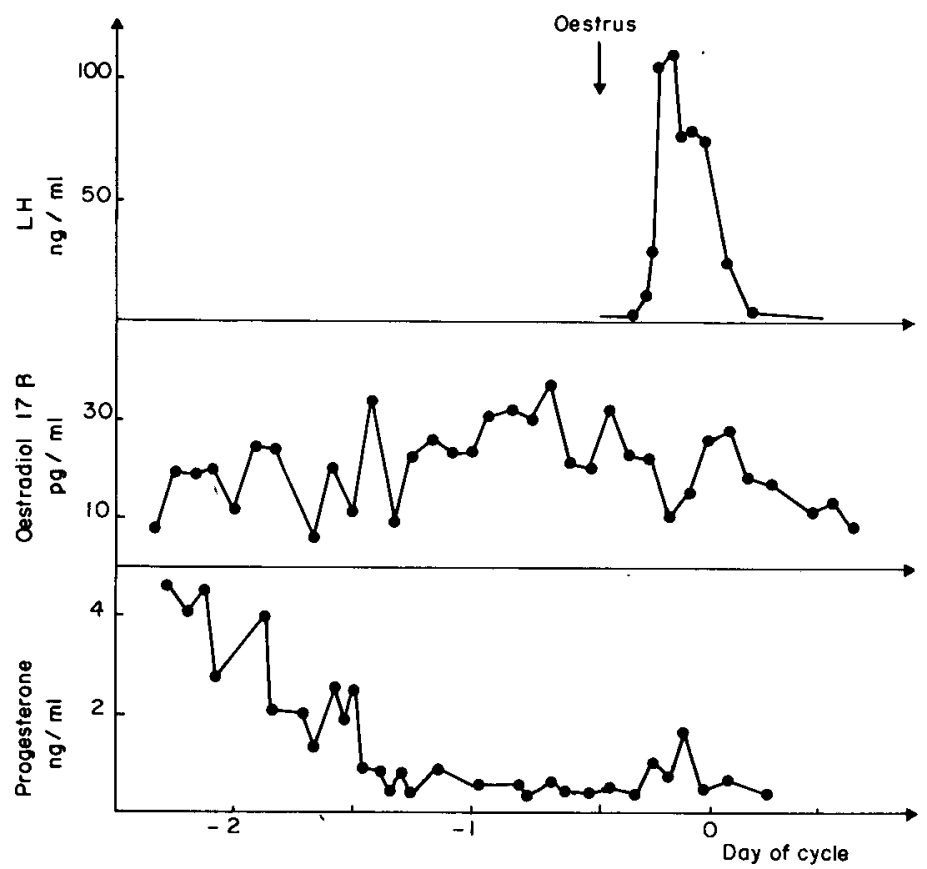

FIG. I. - - Typical patterns of peripheral plasma LH, oestradiol and progesterone during the perioestral period in the ewe

(From Terqui et al., I974 and B. Boursier, I974)

\section{2. - Steroid and $L H$ variations before ovulation in the cow and the sow}

In the cow and sow, the chronology and the direction of variations affecting plasma steroids and LH are roughly similar to those described in the ewe. However, interspecific differences exist, and they reveal in a different manner the relationship between steroids and preovulatory $\mathrm{LH}$ release.

In the cow, plasma progesterone drop is as fast as in the ewe, and occurs between 72 and 48 hours before onset of estrus (SHEMESH et al., Ig68; STABENFEIDT et al., rg69 $b$; HENRICKs et al., I97I). The duration of the follicular phase seems to be under genetic control (LAMOND et al., I97I). The existence of a preovulatory progesterone peak as described by AyALON and SHEMESH (I974) has not been confirmed by others (KATONGOLE et al., I973; LEMON et al., I975). The oestrogen pattern is more debatable. For some authors, an oestradiol peak occurs just before estrus (HENRICKs et al., I97I), and for others, an oestrone peak precedes an oestradiol peak which occurs between 48 and 24 hours before estrus (ECH'TERNKAMP and HANSEL, I97I ; MASON et al., I972). However, the fluorometric methods used by the latter authors show values about Ioo times greater than those found by radioimmunoassay. Meanwhile, the measurement of plasma free immunoreactive oestrogens suggests that $I 7 \beta$-oestradiol is not the main circulating oestrogen, although the identification and the roles of the different oestrogenic components is yet to be defined (LEMon and Saumande, I974). In fact, when the animal is bled frequently 
during a collection period of several days before estrus, the idea of " peak " is not evident (KATONGOLE et al., I973; LEMON et al., 1975), and plasma oestrogen increase is serrate, the maximum sometimes being reached after the onset of estrus. To evaluate the irregular increase, it has been suggested that the slope of the curve representing oestrogen rate increment be established as a function of time (HANCOCK et al., r970).

The LH peak is lower than observed in the ewe $(20-50 \mathrm{ng} / \mathrm{ml}$ vs $50-\mathrm{I} 20 \mathrm{ng} / \mathrm{ml}$ ) (Schams and KARG, I969; Henricks et al., I970 ; Swanson and HAFs, I97I) and begins at the same time as the first manifestations of estrus (SWANSOr and HAFs, I97I ; Cummins et al., I972; LEMON et al., I975). The latter authors observed the behavior of a small sample for a continuous period, and found that there is noticeable synchronization between acceptance of mating and beginning of $\mathrm{LH}$ peak. Finally, in zebu females (Bos indicus), a very short delay between onset of estrus and beginning of LH release has also been observed (CARR, I972).

Differences in progesterone, oestrogen and $\mathrm{LH}$ variations are greater between the sow and the ewe. Due to the high number of corpora lutea, progesterone level reaches $35 \mathrm{ng} / \mathrm{ml}$ during the luteal phase (STABENFELDT et al., I $969 \mathrm{c}$ ). Progesterone drop occurs 6-7 days before onset of estrus, creating a long follicular phase (STABENFELDT et al., I969 $c$; GUTHRIE et al., I972). On the contrary, oestrogens fluctuate between narrow limits ( $10-50 \mathrm{pg} / \mathrm{ml})$, and mean values at the time of the peak occurring I-2 days before estrus are only about two times the value observed during the remaining part of the cycle. It has also been shown that an oestrogen rise occurs after progesterone drop (HENRICKs et al., I972; GưhHRIE et al., I972). However, one of the most noteworthy endocrine characteristics in the sow is the low magnitude

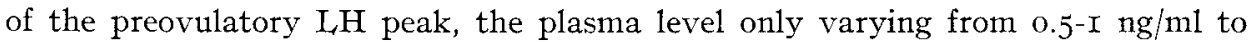
3-4 ng/ml at maximum (NISWENDER et al., I970 ; RADFORD et al., I97I). The length of the surge has not been exactly determined, but might last more than Io hours (HENRICKs et al., I972). The low quantity of $\mathrm{LH}$ released at estrus in a species where the ovulation rate is high, clearly indicates that the number of corpora lutea is not correlated only with preovulatory surge intensity.

Finally, while the succession of endocrine events before ovulation is similar in the three species, the respective roles of oestrogens and progesterone in initiating $\mathrm{L}, \mathrm{H}$ release cannot be exactly defined.

\section{II. - ROLES OF OESTRADIOL}

\section{AND PROGESTERONE IN INITIATING LH RELEASE}

\section{AND THEIR USE FOR ESTRUS CONTROL, IN THE EWE}

\section{I. - Roles of oestradiol and progesterone}

Drop of plasma progesterone, then oestrogen increase before preovulatory $\mathrm{LH}$ release, led to three different hypotheses for domestic animals : a) decrease of plasma progesterone is the signal which initiates $\mathrm{LH}$ release, $b$ ) increase in plasma oestrogens only is responsible for this surge, $c$ ) a third hypothesis considers both 
points $a$ and $b$ as necessary. The findings are most conclusive in the castrated ewe where a progesterone treatment followed by oestradiol benzoate injection not only restores estrous behavior, but induces a " preovulatory )-type surge (PELLETIER and SIGNORET, I969; RADFORD et al., I969). The first hypothesis was discarded when it was later shown that various treatments with progesterone were unable to induce $\mathrm{LH}$ discharge. However, when given at the same time as oestradiol, progesterone inhibited the inducing effect of oestradiol (fig. 2). Finally, it was found

Treatments
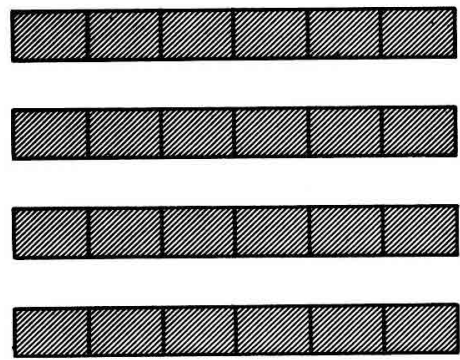

$\mathrm{LH}$ release
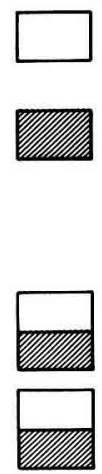

6
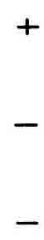

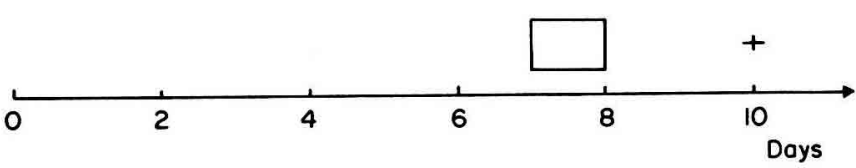

$\mathrm{I}_{\mathrm{IG}}$. 2. - Infuence of various oestradiol benzoate and progesterone treatments on induction of $a$ "preovulatory-type " $L H$ release in the castrasted eve

(From Pelletier and Signoret, I97o)

+ : obtention of L.H release (7o to go p. roo of females) at day 9 or $\mathrm{I} o$ of the artificial cycle.

- : no LH release (Ioo p, Ioo of females)

that an injection of oestradiol benzoate alone was sufficient to induce $L_{H} H$ release in about $90 \mathrm{p}$. IOO of ewes (PELLETIER and SIGNORET, I970). These facts were confirmed in castrated ewe (SCARAmuzzr et al., I97r) and in the ovariectomized cow (Hobson and HANSEL, I972 ; SHORT et al., I973). Thus, oestradiol was considered as the essential agent in initiating preovulatory LH surge. However, while the hypothesis of a per se effect of progesterone decrease (SNook et al., I97I) was discarded, it was thought that progesterone could have an indirect beneficial role on the surge owing to its negative feedback effect limiting tonic $\mathrm{LH}$ release thereby allowing reconstitution of pituitary $\mathrm{L}_{\mathrm{H}} \mathrm{H}$ stock during the luteal phase.

\section{2. - Effects of progesterone or its derivatives on control of $L H$ surge}

Since DUTT and CASIDA (r948) showed that intramuscular injections of progesterone prevented ovulation in the cyclic ewe, this hormone, and particularly some of its synthetic derivatives, have been used to temporarily inhibit estrus and ovula- 
tion and thus to synchronize a group of females. Fluorogestone acetate (FGA, Searle), given by vaginal route (RobInson, I965) prevents $\mathrm{LH}$ surge during the duration of the treatment. It occurs later spontaneously, but the quantity of $\mathrm{LH}$ released represents only $60 \mathrm{p}$. IOO $(\mathrm{P}<\mathrm{o.oI})$ of that released under normal conditions (Pelletier and Thimonier, ig69). Cumming et al. (I97I) have not found any differences between these two groups, but the authors did not calculate the intensity of $\mathrm{L} / \mathrm{H}$ surge.

In the cyclic cow, treatment with melengestrol acetate was not found to modify preovulatory LH surge (WETTEMAN and HAFS, I973) ; curiously, it increased the plasma basal level by roo to I50 p. IOO (HIL, et al., I97I ; RANDEL et al., I972).

In the ewe treated during the seasonal anestrous period, (progestagen treatment is not followed by spontaneous LH release. Consequently, under practical conditions, a progestagen treatment must be associated with a treatment to induce $\mathrm{L}, \mathrm{H}$ release.

\section{3. - Effect of oestradiol on induction of $L H$ release}

The injection of oestradiol induces a preovulatory LH surge in the anestrous ewe (GODING et al., I969; RADFORD et al., I97I ; BECK and REEVEs, I973). Oestradiol acts similarly in the ewe during the sexual season, but only during a short period at onset of the estrous cycle, 3-4 days after estrus when the progesterone level is low (BoL, et al., I97r; Symons et al., I973). These results confirm those of PIPER and Foote (I968) based on ovulation. In the female, oestradiol may induce a preovulatory-type of $\mathrm{L}_{\mathrm{H}} \mathrm{H}$ surge as early as $3^{8}$ days of age (LAND et al., I970). The interval between oestradiol intramuscular injection and beginning of LH surge is about 8-I2 hours, and according to BECK and REEVES (I973) is independent of the dose used in the range of $12.5-200 \mu \mathrm{g}$. According to the same authors, the magnitude of the $\mathrm{I}_{4} \mathrm{H}$ peak is not related to the quantity of oestrogen given. However, oestradiol injected at the end of a progestagen treatment tends to reduce fertility in ewes (RoBINson et al., I970).' This may be due to a synergistic negative feedback effect with the progestagen at the hypothalamo-pituitary level. These results, and the need to induce follicular development in animals in anestrus, have led us to examine other $\mathrm{L} H$ release inducers.

\section{4. - PMSG as an inducer of $L H$ release}

Inducing follicular growth, $\mathrm{LH}$ release and finally superovulation, PMSG is intensively used in ovine (THIMONIER and CoGNIE, I97r) and bovine (MAULEON et al., I970; BELLOWS and SHORT, I972) species. Correlations between oestrogen production and intensity of $\mathrm{LH}$ release $(r=+0.6 \mathrm{I}, \mathrm{P}<0.0 \mathrm{I})$, as well as between quantity of $\mathrm{LH}$ released and ovulation rate $(r=+0.7 \mathrm{I}, \mathrm{P}<0.0 \mathrm{I})$ have been demonstrated in cattle (SAUMANDE and PeLLETIER, I975).

After interruption of progestagen treatment (vaginal FGA) in the cyclic ewe, PMSG induces a surge of LH similar to that in natural conditions (PELLETIER and Thimonier, I969). However, some difficulties remain. In addition to the appearance of a refractory period leading to reduced ovulation rate following its repeated use (HAFEZ et al., I965; HuI,ET and FooTE, I969), this hormone, reinforced or not 


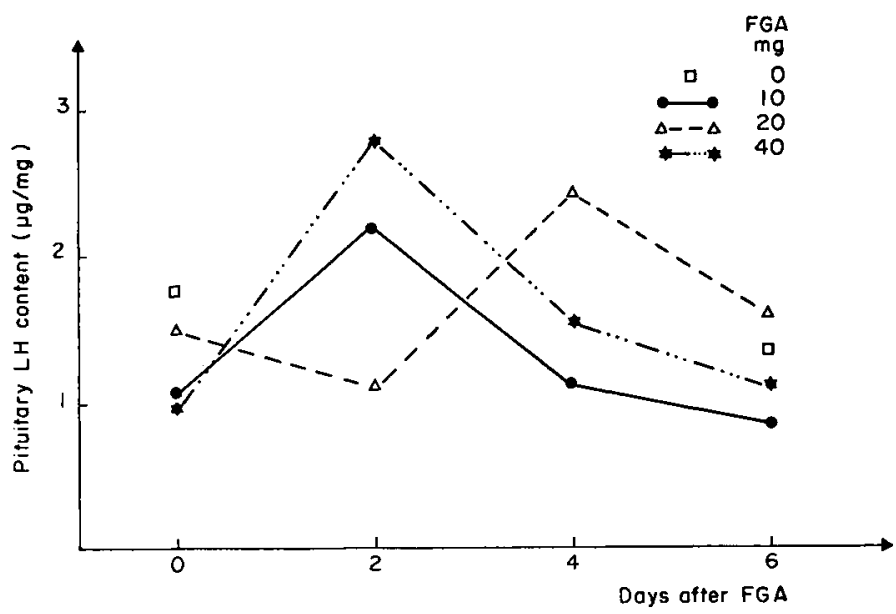

Frg. 3. - Variations in pituitary LH content after various progestagen treatments (FGA, I2 days) in the lactating ewe during the period of seasonal anoestrum. Start of treatment 40 days after parturition;

three females per group sacrificed at each time of slaughter

(Pelletier and Thimonier, unpublished results)

\section{TABLE I}

Variation of intensity of preovulatory $L H$ surge in lactating ewes during seasonal anestrous as related to the interval "End of progestagen treatment-PMSG injection"

(Pelletier and Cognie, unpublished data)

\begin{tabular}{|c|c|c|c|c|c|c|}
\hline \multirow{2}{*}{\multicolumn{2}{|c|}{ Grp. Phys. State }} & \multirow{2}{*}{$n$} & \multirow{2}{*}{$\begin{array}{c}\text { FGA treatment } \\
\text { length (1) } \\
\text { (days) }\end{array}$} & \multirow{2}{*}{$\begin{array}{c}\text { FGA-PMSG }\left({ }^{2}\right) \\
\text { interval } \\
\text { (hours) }\end{array}$} & \multicolumn{2}{|c|}{ LH release $\left({ }^{3}\right)$} \\
\hline & & & & & $\mathrm{mm}^{2}$ & p. 100 \\
\hline \multicolumn{7}{|l|}{--} \\
\hline 1. Dry ew & & 7 & 12 & 0 & $3773 \pm 378$ & 1110 \\
\hline 2. Lactati & ewe & 7 & 12 & 0 & $2892 \pm 350$ & 76.6 \\
\hline 3. $\quad-$ & - & 7 & 6 & 0 & $2734 \pm 267$ & 72.5 \\
\hline$\longrightarrow$ & - & 7 & i; & 12 & $3142 \pm 126$ & 83.3 \\
\hline$\longrightarrow$ & 一 & 7 & b; & 24 & $2966 \pm 487$ & 78.6 \\
\hline- & - & 7 & ti & 36 & $2270 \pm 223$ & 60.2 \\
\hline- & - & 7 & bi & 48 & $2189 \pm 261$ & 58.0 \\
\hline
\end{tabular}

(1) FGA : $40 \mathrm{mg}$.

(2) PMSG : $600 \mathrm{IU}$ (dry ewes) and 750 IU (lactating ewes).

${ }^{3}{ }^{3} \mathrm{LH}$ release estimated from the area under the LII curve.

(4) All females ovulated except two in grp. 6. 
by oestrogens, induces an $\mathrm{LH}$ surge in lactating ewes during seasonal anestrus which is only $65 \mathrm{p}$. Ioo of that in dry ewes (PEILLETIER and ThIMONIER, I973).

A study of variation of pituitary $\mathrm{LH}$ content in lactating females treated with progestagen in the non-sexual season indicates that the content increases after the treatment is discontinued (fig. 3). We have tried to improve PMSG efficiency in lactating females by studying the influence of the interval " withdrawal of progestagen treatment-injection of PMSG " on the intensity of $\mathrm{L} / \mathrm{H}$ release (table I). As compared to an interval equal to zero, a I2-hour interval slightly improves the quantity of $\mathrm{LH}$ released; however, it represents only $83 \mathrm{p}$. Ioo of that observed in dry ewes (PELLETIER and COGNIE, unpublished results). When this interval is greater than 24 hours, $\mathrm{L}_{4} \mathrm{H}$ release is reduced. The latter result and the difficulty in using homogeneous lots of PMSG have led us to examine the effect of other $\mathrm{LH}$-release inducers, namely the recently synthesized LH-releasing factor (LRF) (MATsuo et al., I97I).

\section{5. - LRF as inducer of $L H$ release}

The injection of LRF induces a LH surge in ewes (REEVES et al., 1970, 1972; Cumming et al., I972; White et al., I973 ; RIPPer et al., I974 ; SEgERson et al., I974), cows (Zolman et al., I973; KalTENBACr et al., I974) and sows (BAKER et al., I973;

TABLE 2

Effect of lactation on intensity of preovulatory LH surge induced in seasonal anestrous ewe

\begin{tabular}{|c|c|c|c|c|}
\hline & $n$ & $\begin{array}{c}\text { Interval } \\
\text { PMSG-LRF } \\
\text { (hours) }\end{array}$ & $\begin{array}{c}\text { LH release } \\
(\mathrm{ng} / \mathrm{m} 1 / 1 \mathrm{~h})\left({ }^{1}\right)\end{array}$ & $\begin{array}{l}\text { Peak value } \\
(\mathrm{ng} / \mathrm{ml})\end{array}$ \\
\hline Dry ewes & $\begin{array}{l}6 \\
6\end{array}$ & $\begin{array}{l}24 \\
30\end{array}$ & $\begin{array}{l}313 \pm 47.0 \\
279 \pm 44.3\end{array}$ & $\begin{array}{l}111.5 \pm 19.1 \\
104.7 \pm 12.9\end{array}$ \\
\hline Lactating ewes & $\begin{array}{l}6 \\
6\end{array}$ & $\begin{array}{l}21 \\
30\end{array}$ & $\begin{array}{l}169 \pm 30.0 \\
177 \pm 29.7\end{array}$ & $\begin{array}{l}68.0 \pm 9.0 \\
76.6 \pm 10.9\end{array}$ \\
\hline
\end{tabular}

(1) Mean $\doteq$ S. F. M.

Chanraborty et al., I973). Preovulatory $\mathrm{LH}_{\mathrm{H}}$ release similar to that of a normal estrous cycle is obtained in the dry ewe, previously treated with progestagen in seasonal anestrus and given an LRF injection 24 hours after a reduced PMSG injection (PELLETIER, I974). We thought that LRF would quantitatively restore induced $\mathrm{LH}$ release in the lactating ewe during seasonal anestrus. However, induced $\mathrm{LH}$ release, in these conditions, represents only $60 \mathrm{p}$. Ioo of that in dry ewes (PELIETIER, I974) (table 2). As pituitary LH content of lactating ewes does not differ greatly from dry ewes, we must conclude that $\mathrm{LH}$ release is not due to simple LRF effect, but is a result of interaction between the LRF and other hormones. 


\section{III. - FEEDBACK EFFECT OF STEROIDS AT HYPOTHALAMIC}

\section{AND PITUITARY LEVELS}

\section{I. - At the hypothalamic level}

It is admitted that ovarian steroid production, which is stimulated by gonadotropins, exerts a feedback effect at the hypothalamic level. However, this general concept largely lacked physiological or direct experimental demonstration by plasma LRF assay until recently. In I970, SCHNEIDER and MCCANN presented a scheme of oestradiol negative feedback effect on LRF release via synthesis of a regulating protein, but these authors did not consider the positive feedback effect at the time of preovulatory surge. This effect, however, is highly probable since a $5^{\circ} \mathrm{p}$. Ioo decrease in hypothalamic LRF content (CRIGHToN et al., I973) and a plasma LRF increase from less than $0.5 \mathrm{ng} / \mathrm{ml}$ to $6 \mathrm{ng} / \mathrm{ml}$ (KERDELHUE and JU'TISZ, I972) are simultaneous with preovulatory LH surge. Furthermore, RADFORD and WALLACE (I974) have shown that in castrated ewes, induction of LH release by oestrogen is delayed while animals were under anesthesia. This clearly suggests a central oestradiol effect.

While the mode of positive oestradiol action at the hypothalamic level is not exactly known, sexual steroids could exert an inhibiting effect via decrease in LRF synthesis, as it has been suggested for testosterone in ram (PELLETIER, I970). After a 6-day treatment with the FGA (40 $\mathrm{mg}$ ) administered by vaginal route, a 35 p. Ioo decrease in LRF hypothalamic content is observed in the dry ewe (PELLETIER and THIMONIER, I972). On the other hand, if the same dose of FGA is given for I2 days, a $30 \mathrm{p}$. Ioo increase in LRF hypothalamic content is obtained. This could result from rebound effect, namely increased synthesis following the period of inhibition. In present conditions, such a phenomenon is possible since there is a daily decrease of about $16 \mathrm{p}$. Ioo in the quantity of FGA released from the raginal sponge (MoRGaN et al., I967). However, the same treatment given to lactating females induces a decrease in hypothalamic LRF content of $I_{5}$ and $32 \mathrm{p}$. Ioo for 20 and $40 \mathrm{mg}$ of FGA, respectively, even after $\mathrm{I} 2$ days of treatment (PELLETIER and Thimonier, I972). It is unlikely that anestrus would be due to a lack of LRF in the hypothalamus (JACKSON et al., I97I), but would more probably result from the absence of a signal for preovulatory surge.

\section{2. - At the pituitary level}

In I970, REEVES et al. showed that LH release induced by purified LRF was greater when the injection was given to ewes in estrus than to ewes at other stages of the estrous cycle. These authors concluded that pituitary responsiveness to LRF is modified by circulating steroids. It has been further shown that oestradiol increases pituitary responsiveness to LRF in the ewe (REEVES et al., I97I), cow (ZoLMAN et al., I974), woman (YEN et al., I972) and rat (ARIMURA and SCHALLY, I97I). The role of progesterone, however, is less clear; it has been found to block LH release induced by intrapituitary infusion of LRF in the rabbit (HIIIIARD et al., I97I), 
but not in the ewe (Cumming et al., 1972). In the latter case, however, progesterone given by intravenous infusion was not measured in the blood to check the level during infusion.

Thus, we injected ewes with $25 \mu \mathrm{g}$ of synthetic LRF at day 4,8 , I2 or I6 of the estrous cycle; $\mathrm{I} 7 \beta$-oestradiol and progesterone plasma levels were measured before $\mathrm{LRF}$ injection. Mean $\mathrm{LH}$ response for days 4,8 and $\mathrm{I} 2$ is 39 , I6 and I $3.5 \mathrm{p}$. Ioo, respectively, of that observed on day I6 (fig. 4) (THIMONiER et al., I974). It appears
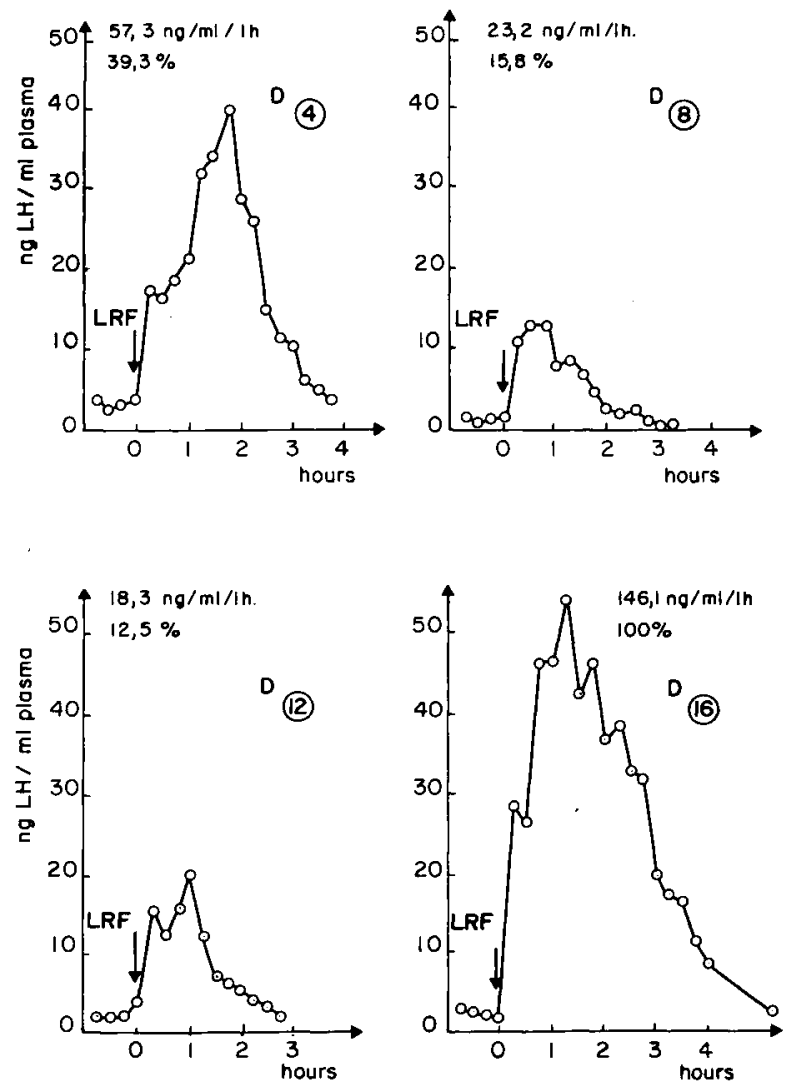

FiG. 4. - Variation of $L H$ response to $L R F$ in a typical ewe injected at day 4, 8, 12 or 16 of the oestrous cycle (IV injection of $25 \mu \mathrm{g} \mathrm{LRI} ; 3$ O/group)

(From Thimonier et al., I974)

that intensity of $\mathrm{LH}$ release is better correlated with the oestradio1/progesterone ratio than with the oestrogen or progesterone plasma level. In the present experiment, the correlation coefficient between the logarithm of $\mathrm{LH}$ response to $\mathrm{LRF}$ and the oestradiol/progesterone ratio is $+0.97(\mathrm{P}<0.05)$. SyMONS et al. (I974) and RIPPEL, et al. (1974) found no variation in $\mathrm{L}_{\mathrm{H}} \mathrm{H}$ response to $\mathrm{L}_{\mathrm{RF}}$ during the ewe estrous cycle, but it may be that these authors did not choose the times of maximal oestradiol/ progesterone ratio variation during the cycle. If the plasma oestrogen/progesterone ratio is of importance in order to induce LH release with LRF, a difference in pituitary responsiveness to LRF could explain that releasing-factor in lactating ewes 
has a weaker effect than in dry ewes. In fact, CoGNIE et al. (I974) have shown that in lactating ewes pretreated with progestagen during the seasonal anestrus, the I $7 \beta$-oestradiol plasma level was lower than in dry ewes treated in the same conditions.

Similarly, it is likely that a variation in pituitary responsiveness to LRF could explain the cessation of preovulatory release. The interruption would not be due to a lack of $L_{1 R F}$ since this would be released after the end of $\mathrm{L}_{4} \mathrm{H}$ surge (KERDELHUE and JUTISZ, I972 ; FOSTER et al, I974). On the contrary, we previously suggested (PELLETIER and SIGNORET, I969, I970) that the greater duration of oestrogen-induced $\mathrm{LH}$ release in the castrated ewe as compared to the entire female could be due to lack of negative feedback in absence of ovarian steroids. It would be interesting to find out if such a feedback mechanism acts at the pituitary level.

\section{CONCLUSION}

The dates of the studies cited clearly indicate the extent of recent progress, since $90 \mathrm{p}$. Ioo of the references included date from the last 6 years. Among the major facts recently exposed, it is seen that the respective roles of oestrogens and progesterone in initiating $\mathrm{L}_{\mathrm{H}} \mathrm{H}$ release have been determined. Furthermore, the purification and synthesis of I,RF permit the demonstration of a direct steroid feedback effect at the pituitary level, thus greatly improving our knowledge of the relationships between hypothalamus, pituitary and gonads. Finally, plasma LH and steroid patterns have been described during the estrous cycle of a number of species.

The present orientation of research should be to improve our knowledge of hypothalamus "physiology ", i.e. variations in LRF synthesis and release during the cycle, and the external and internal factors of regulaion.

These fundamental improvements in domestic animals will undoubtedly have a strong influence on the techniques of reproduction control.

Colloque : Control of sexual cycles in domestic animals October 27-30, 1974, Nouzilly.

\section{ACKNOWLEDGEMENTS}

We would like to thank the Searle Company for its generous financial help in the studies on lactating ewes.

\section{RÉSUMÉ}

IN'TERACTIONS ENTRE $\mathrm{I}_{\mathrm{A}}$ SS STÉROÏDES OU L,ES PROGESTAGÈNES

E,T LA DÉCHARGE, DE, LH

Il est admis aujourd'hui que la décharge préovulatoire de LH chez les mammifères domestiques est reliée à une sécrétion préalable d'œstrogènes par l'ovaire. Une augmentation d'cestradiol- 7 $\beta$ dans le sang précède le pic de LH dans les conditions naturelles pendant la saison 
sexuelle, mais une telle décharge peut être également induite expérimentalement par injection d'œestrogène soit chez la Brebis en anœstrus soit chez la femelle castrée. Ainsi l'injection de $50 \mu \mathrm{g}$ de benzoate d'œstradiol induit chez la brebis castrée, dans $90 \mathrm{p}$. Ioo des cas un pic de LH de même amplitude mais de durée plus longue ( $16 \mathrm{~h} 30$ vs Io $\mathrm{h} 30, \mathrm{P}<0$,or) que celui observé lors du cycle cestrien. Inversement, la progestérone, bien qu'ayant probablement un effet positif indirect sur la décharge préovulatoire de $\mathrm{LH}$, apparaît essentiellement inhibitrice dans les conditions expérimentales : aucune femelle castrée ne présente un pic de LH soit après une injection $(25 \mathrm{mg})$ soit après une série d'injections. De plus la progestérone empêche dans tous les cas $(4 \mathrm{à}$ 8 femelles par groupe) l'effet positif de l'œestradiol.

On connaît mal le mode d'action des stétoïdes au niveau de l'hypothalamus, mais il est probable que l'effet positif de l'œstradiol sur la décharge de LH et l'effet négatif de la progestérone sont exercés à ce niveau. L'influence des œstrogènes est suggérée par une diminution de $50 \mathrm{p}$. 100 du contenu hypothalamique en LRF lors du pic de $\mathrm{LH}$, interprétée comme une libération massive de ce facteur de décharge. L'effet de la progestérone peut être déduit d'une étude effectuée chez la brebis allaitante où le progestagène $(F G A)$ a été trouvé provoquer une diminution du contenu hypothalamique en LRF mais sans pic de LH concomitant. Cette diminution atteint I5 et $32 \mathrm{p}$. Ioo du contenu hypothalamique de brebis témoins chez des femelles traitées pendant I 2 jours respectivement avec 20 ou $40 \mathrm{mg}$ de FGA.

Une démonstration encore plus récente de l'interrelation entre les stëroïdes et l'activité hypothalamo-hypophysaire est la variation de la sensibilité de l'hypophyse au cours du cycle œestrien. Ainsi chez la Brebis, une injection intraveineuse de LRF induit une décharge de LH dont l'intensité varie en fonction du moment du cycle où cette injection est effectuée. La réponse moyenne de LH après une injection de $25 \mu \mathrm{g}$ de LRF est respectivement de 57,23 , I 8 et $146 \mathrm{ng} / \mathrm{ml}$ I $h$ lorsque le LRF est administré à des brebis aux jours 4, 8, I2 ou I6 du cycle oestrien. Cette réponse de LH au LRF est corrélée avec le rapport cestrogène/progestérone dans le sang $(r=0,97, \mathrm{P}<0,05)$ qui apparait ainsi réguler l'effet du LRF au niveau hypophysaire.

\section{REFERENCES}

Arimura A., Schally A. V., I97t. Augmentation of pituitary responsiveness to LH-Releasing Hormone (LH-RH) by estrogen. Proc. Soc. exp. Biol. Med., 136, 290-293.

Ayalon N., Shemesh M., I974. Pro-oestrous surge in plasma progesterone in the cow. J. Reprod. Fert., 36, 239-243.

Baker R. D., Downey B. R., Brinkley H. J., I973. Induction of ovulation in pigs with gonadotrophin releasing hormone. J. Anim. Sci, 37, г376-1379.

Beck T. W., ReEves J. J., 1973. Serum luteinizing-hormone (LH) in ewes treated with various dosilges of $I 7 \beta$-estradiol at three stages of the anestrous season. J. Anim. Sci, 36, 566-570.

Bellows R. A., Short R. E., I972. Superovulation and multiple births in beef cattle. J. Anim. ici. 34, suppl. I, 66 .

Bjersing L., Hay M. F., Kann G., Moor R. M., Naftolin F., Scaramuzzi R. J., Short R. V., YounglaI E. V., 1972. Changes in gonadotrophins, ovarian steroids and follicular morphology in sheep at oestrus. J.Endocr., 52, 465-479.

Boursier B., 1974. Contrôle par les hormones gonadotropes de la secrétion de progestérone ches la Brebis

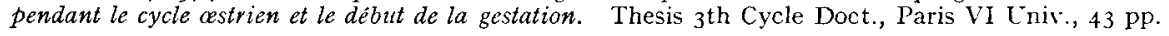

Bolt D. J., Kelley H. E., HAwK H. W., I97I. Release of LH by estradiol in cycling ewes. Biol. Reprod., 4, 35-40.

CARR W. R., I972. Radioimmunoassay of luteinizing hormone in the blood of Zebu cattle. J. Reprod. Fert., 29, II-I8.

Chakraborty P. K., Reeves J. J., Arimura A., Schally A. V., i973. Serum Lh Ievels in prepubertal female pigs chronically treated with synthetic luteinizing hormone-releasing hormone/folliclestimulating hormone-releasing hormone. Endocrinology, 92, 55-61.

Cognie Y., Hernandez-Barreto M., Saumande J., 1975 . Low fertility in lactating ewes during the non-breeding season. Ann. Biol. anim. Biochim. Biophys., 15, 329-343.

Cox R. I., Mattner P. E., Thorburn G. D., I97I. Changes in ovarian secretion of oestradiol-I7\% around oestrus in the sheep. J. Endocr., 49, 345-346.

Crighton D. B., Hartley B., Lamming G. E., 1973. Changes in the LH releasing activity of hypothalamus and in pituitary gland and plasma LH during the oestrous cycle of the sheep. $j$. Endocr., $58,377-385$.

Cumming I. A., Blockey M. A. (de B.), Brown J. M., Catt K. J., Goding J. R., Kaltex Bach C. C., I970. The release of luteinizing hormone in ewes following the withdrawal of intravaginal sponges containing progestagen. Proc. aust. Soc., 8, 383-387. 
Cumming I. A., Brown J. M., Blockey M. A. (de B.), Winfield G. G., Baxter R., Goding J. R., 1971. Constancy of interval between LH release and ovulation in the ewe. J. Reprod. Fert., 24, I34-135.

Cumming I. A., Buckmaster J. M., Cerini J. C., Cerini M. E., Chamley W. A., Findlay J. K., GoDing J. R., r972. Effect of progesterone on the release of luteinizing hormone induced by a synthetic gonadotrophin-releasing factor in the ewe. Neuroendocrinology, 10, 338-348.

Cummins L. J., Blockey M. A. (de B.), Brown J. M., Goding J. R., I972. A study of luteinizing hormone secretion in the cow. J. Reprod. Fert., 28, I35 (abstr.).

Dutt R. H., Casida L. E., I948. Alteration of the estrial cycle in sheep by use of progesterone and its effect upon subsequent ovulation and fertility. Endocrinology, 43, 208-217.

Echternkamp S. E., Hansel W., r97r. Plasma estrogens, luteinizing hormone and corticoid in postpartum cows. J. Dairy Sci., 54, 800 (abstr.).

lioster J. P., Holland D. T., Jeffcoate S. L., Crighton D. B., I974. Simultaneous determination by radioimmunoassay of $\mathrm{LH}$ and $\mathrm{LH}-\mathrm{RH}$ at different stages of the oestrous cycle in the sheep. J. Endocr., 61, LXIII (abstr).

Geschwind I. I., Dewey R., Ig68. Dynamics of luteinizing hormone secretion in the cycling ewe : a radioimmunoassay study. Proc. Soc. exp. Biol. Med., 129, 45 I-455.

Goding J. R., Catt K. J., Brown J. M., Kaltenbach C. C., Cumming I. A., Mole B. J., I969. Radioimmunoassay for ovine luteinizing hormone. Secretion of luteinizing hormone during estrus and following estrogen administration in the sheep. Endocrinology, 85, I33-I42.

Guthrie H. D., Henricks D. M., Handlin D. L., I972. Plasma estrogen, progesterone and luteinizing hormone prior to estrus and during early pregnancy in pigs. Endocrinology, 91, 675-679.

HaFez E. S. E., Jainudeen M. R., Lindsay D. R., I965. Gonadotropin induced twinning and related phenomena in beef cattle. Acta Endocr., 50, Suppl. 102, 5-43.

Hammond J. Jr, 1945. Induced ovulation and heat in anoestrus sheep. J. Endocr., 4, I69-180.

Hancock K. W., Scott J.S., Stitch S. R., Levell M. J., OAKey R. E., Ellis F. R., I97o. Problems of prediction of response to gonadotrophins. Lancet, ii, $482-485$.

Henricks D. M., Dickey J. F., I97o. Serum luteinizing hormone and plasma progesterone levels during the estrous cycle and early pregnancy in cows. Biol. Reprod., 2, 346-35I.

Henricks D. M., Dickey J. F., Hill J. R., ig7r. Plasma estrogen and progesterone levels in cows prior to and during estrus. Endocrinology, 89, I350-1355.

Henricks D. M., Guthrie H, D., Handil D. L., I972. Plasma estrogen, progesterone and luteinizing hormone levels during the estrous cycle in pigs. Biol. Reprod., 6, 2 I0-2 18.

Henricks D. M., Hil. J. R., Dickey J. F., I973. Plasma ovarian hormone levels and fertility in beef heifers treated with melengestrol acetate (MGA). J. Anim. Sci., 37, I I69-I I75.

Henricks D. M., Hill J. R., Dickey J. F., Lamond D. R., 1973. Plasma hormone levels in beef cows with induced multiple ovulation. J. Reprod. Fert., 35, 225-233.

Hill J. R. Jr, Lamond D. R., Henricks D. M., Dickey J. F., Niswender G. D., I97i. The effect of melengestrol acetate (MGA) on ovarian function and fertilization in beef heifers. Biol. Reprod., 4, I6-22.

Hilliard J., Schally A. V., Sawyer C. H., I97I. Progesterone blockade of the ovulatory response to intrapituitary infusion of LH-RH in rabbits. Endocrinology, 88, 730-736.

Hobson W. C., HANsel W., I972. Plasma LH levels after ovariectomy, corpus luteum removal and estradiol administration in cattle. Endocrinology, 91, 185-189.

HoHLweG W., I934. Veränderungen des hypophysen-vorderlappens und des ovariums nach Behandlingen mit grossen Dosen von follikelhormon. Klin. Wchnshr., 13, 92-95.

Hulet C. V., Foote W. C., I969. Ovulatory response of the ewe to repeated injection of PMS. $J$. Anim. Sci., 29, 457-463.

Jackson G. L., Roche J. F., Foster D. L., DzIUk J. P., I97r. Luteinizing hormone releasing activity in the hypothalamus of anoestrous and cyclic ewes. Biol. Reprod., 5 5-12.

Kaltenbach C. C., Dunn T. G., Kiser T. E., Corah L. R., Akbar A. M., Niswender G. D., I974. Release of FSH and LH in beef heifers by synthetic gonadotrophin releasing hormone. $J$. Anim. Sci., 38, 357-362.

Katongole C. B., Naftolin F., Younglai E. V., 1973. Diurnal variations in ovarian steroids and luteinizing hormone in cows at oestrus. Steroids Lipids Res., 4, I-5.

KErdelive B., Jutisz M., x972. Development of a radioimmunoassay of a hypothalamic hormone which stimulate the release of pituitary $\mathrm{LH}$ and $\mathrm{FSH}$ (LH-RH) using a synthetic decapeptid as antigen. 4th intern. Cong. Endocr., Washington, Excerpta Medica, Amsterdam., I4I (abstr. 352).

Lamond D. R., Henricks D. M., Hill J. R. Jr, Dickey J. F., r97r. Breed differences in plasma progesterone concentration in the bovine during proestrus. Biol. Reprod., 5, 258-26r.

Land R. B., Thimonier J., Pelletier J., i97o. Possibilité d'induction d'une décharge de LH par une injection d'oestrogène chez l'agneau femelle en fonction de l'âge. C. R. Acad. Sc., Ser. D., 271, I 549-I 55 I.

Land R. B., Pelletier J., Thimonier J., Mauleon P., I973. A quantitative study of genetic differences in the incidence of oestrus, ovulation and plasma luteinizing hormone concentration in the sheep. J. Endocr., 58, 305-317. 
Lemon M., Pelletier J., Saumande J., Signoret J. P., I975. Peripheral plasma concentrations of p rogesterone, oestradiol-I $>\beta$ and luteinizing hormone around oestrus in the cow. J. Reprod. Fert. (In press).

Lemon M., Saumande J., I974. The evolution of ovarian steroid hormones during luteolysis and folliculogenesis in the cow. Europ. J. Obst. Gynaec. Reprod. Biol., 4, Suppl., 569-575.

Mason B. D., Krishnamurti C. R., Kitts W. D., I972. Oestrone and oestradiol in jugular vein plasma during the oestrous cycle of the cow. $j$. Endocr., 55, I4I-I46.

Matsuo H., Baba Y., Nair R. M. G., Arimura A., Schally A. V., ig7i. Structure of the porcine LH-and FSH-releasing hormone. The proposed amino acid sequence. Biochem. biophys. Res. Comm., 43, 1334 - 1339 .

Mauleon P., Mariana J. C., Benoit M., Solari A., Chupin D., ig7o. Influence de différentes doses de PMSG et HCG injectées en phase folliculaire du cycle cestrien sur le nombre et le rendement d'ovulations de vaches de race Française Frisonne Pie Noire. Ann. Biol. anim. Bioch. Biophys., 10, $n^{0}$ hors série, $\mathrm{r}, 3 \mathrm{I}-46$.

Moore N. W., Barrett S., Brown J. B., Schindler I., Smiti M. A., Smyth B., ig69. Oestrogen and progesterone content of ovarian vein blood of the ewe during the estrous cycle. $J$. Endocr., 44, $55-62$.

Morgan J., Lack R. E., Robinson T. J., I 967 . The rate of absorption of SC 9880 from impregnated sponges inserted intravaginally in cyclic crossbred ewes. In The control of the ovarian cycle in sheep, T. J. Robinson Ed., Sydney Univ. Press, 195-207.

Niswender G. D., Roche J. F., Foster D. L., Midgley A. R. Jr, 1968. Radioimmumoassay of serum levels of luteinizing hormone during the cycle and early pregnancy in ewes. Proc. Soc. exp. Biol. Med., 129, 901-904.

Niswender G. D., Reichert L. E., Zrmmerman D. R., i97o. Radioimmunoassay of serum level of luteinizing hormone throughout the estrous cycle in pigs. Endocrinology, 87, 576-580.

Pelletier J., i97o. Mode of action of testosterone propionate on the secretion and release of luteinizing hormone $(\mathrm{LH})$ in the castrated ram. Acta Endocr., 63, 290-298.

Pelletier J., I974. Influence de la lactation sur la décharge préovulatoire de LH induite par l'injection de LRF synthétique chez la Brebis durant la période d'anœstrus saisonnier. C. R. Acad. Sc., Paris, Ser. D, 279, I79-I 82.

Pelletier J., Kann G., Dolais J., Rosselin G., I968. Dosage radioimmunologique de l'hormone lutéinisante plasmatique chez le Mouton. Comparaison avec le dosage biologique de LH par la diminution de l'acide ascorbique ovarien et exemple d'application aux mesures de la LH sanguine chez la Brebis. C. R. Acad. Sc., Paris, Ser. D, 266, $2352-2354$.

Pelletier J., Signoret J. P., i 969 . Contrôle de la décharge de LH dans le sang par la progestérone et le benzoate d'œestradiol chez la brebis castrée. C. R. Acad. Sc., Paris, Ser. D., 269, 2595-2598.

Pelletier J., Signoret J. P., rgjo. Influences respectives de l'œstradiol et de la progestérone sur la décharge de LH dans le sang de la brebis castrée. Coll. Soc. natn. Étud. Steril. Fecond. : L'inhibition de l'ovulation, Ed Masson et Cie, 215-223.

Pelletier J., Thimonier J., ig69. Etude de la décharge ovulante par dosage radioimmunologique de la LH plasmatique chez la brebis normale ou traitée par un progestagène. C. $R$. Acad. Sc., Paris, Ser. D, 268, $573-576$.

Pelletier J., Thimonier J., I972. Influence of fluorogestone acetate (FGA) on hypothalamo-hypophysial activity in anoestrus dry and lactating ewes. J. Reprod. Fert., 31, 496-497.

Pelletier J., Thimonier J., 1973. Comparison of the induced preovulatory LH discharge in lactatings and dry sheep during seasonal anoestrus. J. Reprod. Fert., 33, 310-313.

Piper E. L., Foote W. C., 1968. Ovulation and corpus luteum maintenance in ewes treated with I73-oestradiol. J. Reprod. Fert., 16, 253-259.

Radford H. M., Wallace A. L., Wheatley I. S., I97I. Steroid-induced gonadotrophin release in the ewe. J. Reprod. Fert., 24, I47-I48.

RADFord H. M. Wallace A. L., I974. Central nervous bockade of oestradiol stimulated-release of luteinizing hormone in the ewe. J. Endocr., 60, $247-252$.

Radford H. M., Wheatley I. S., Wallace A. L., ig69. The effects of oestradiol benzoate and progesterone on secretions of luteinizing hormone in the ovariectomized ewe. J. Fndocr., 44, $135-136$.

Randel R. D., Callahan C. J., Erb R. E., Garverick H. A., Brown B. L., i972. Effect of melengestrol acetate on plasma progesterone, luteinizing hormone and total corticoids in dairy heifers. $J$. Anim. Sci., 35, 389-397.

RAyford P. L., BRINKLeX H. J., Young E. P., I97r. Radioimmunoassay determination of LH concentration in the serum of female pigs. Endocrinology, 88, 707-713.

Reeves J. J., Arimura A., Schally A. V., I97o. Different responses to LH-RH in wethers and ewes, and at various stages of the estrous cycle in ewes. J. Anim., Sci., 31, 228.

Reeves J. J., Arimura A., Schally A. V., I97I. Changes in pituitary responsiveness to luteinizinghormone releasing hormone (LH-RH) in anoestrous ewes pretreated with estradiol benzoate. Biol. Reprod., 4, 88-92.

Reeves J. J., Arimura A., Schally A. V., KraG T C. L., Beck T. W., Casey J. M., r972. Effects of synthetic luteinizing hormone-releasing hormone/follicule-stimulating hormone releasing hormone 
(LH-RH/FSH-RH) on serum LH, serum FSH and ovulation in anoestrus ewes. J. Anim. Sci., 35, 84-89.

Rippel R. M., Moyer R. H., Johnson E. S., Mauer R. E., I974. Response of the ewe to synthetic gonadotropin releasing hormone. J. Anim. Sci., 38, 605-6r2.

Robinson T. J., r954. The necessity of progesterone with estrogen for the induction of recurrent estrus in the ovariectomized ewe. Endocrinology, 55, 403-408.

RoBinson T. J., 1965. Use of progestagen-impregnated sponges inserted intravaginally or subcutaneously for the control of the oestrous cycle in the sheep. Nature, 206, 39-4I.

Robingon T. J., Moore N. W., Lindsay D. R., Fletcher I. C., Salamon S., i97o. Fertility following synchronization of oestrus in the sheep with intravaginal sponges. I. Effects of vaginal douche, supplementary steroids, time of insemination, and numbers of dilution of spermatozoa. Aust. J. agric. Res., 21, 767-78I.

Saumande J., Pelletier J., 1975. Relationship of plasma levels of oestradiol-17 $\beta$ and luteinizing hormone with ovulation rate in pregnant mare serum gonadotrophin superovulated cattle. $J$. Endocr. (in press).

Scaramlzzi R. J., Caldwell B. V., Moor R. M., I97o. Radioimmunoassay of LH and estrogen during the estrous cycle of the ewe. Biol. Reprod., 3, IIo-IIg.

Scaramuzzi R. J., Tillson S. A., Thorneycroft I. H., Caldwell B. V., I97i. Action of exogenous progesterone and estrogen on the behavioral estrous and luteinzing hormone levels in the ovariectomized ewe. Endocrinology, 88, I I84-I I89.

Schams D., KaRG H., I969. Radioimmunologische LH-Bestimmung in Blutserum vom Rind unter besonderer Berücksichtigung des Brunstzyklus, Acta Endocr., 61, 96-103.

Schneider H. P. G., McCann S. M., I970. Estradiol and the neuroendocrine control of LH release in vitro. Endocrinology, 87, 330-338.

Segerson E. C. Jr., Ulberg L. C., Martin J. E., Fellows R. E., I974. Fertility in ewes treated with luteinizing hormone releasing factor. Proc. Soc. exp. Biol. Med., 146, 5 I8-521.

Shemesh M., AYalon N., Lidner H. R., I968. Plasma progesterone concentrations in dairy cows during the estrous cycle. Refuah. Vet., 25, 265-270.

Short R. E., Howland B. E., Randel R. D., Christensen $\quad$ D. S., Bellows R. A., i973. Induced LH release in spayed cows. J. Anim. Sci, 37, 55I-557.

Snook R. B., SaAtman R. R., Hansel W., r97i. Serum progesterone and luteinizing hormone levels during the bovine estrous cycle. Endocrinology, 88, 678-686.

Stabenfeldt G. H., Holt J. A., Ewing L. L., r969a. Peripheral plasma progesterone levels during the ovine estrous cycle. Endocrinology, 85, I I-I5.

Stabenfeldt G. H., Ewing L. L., McDonald L. E., I $969 b$. Peripheral plasma progesterone levels during the bovine oestrous cycle. J. Reprod. Fert. 19, 433-442.

Stabenfeidt G. H., Akins E. L., Ewing L. L., Morrissette M. C., I969c. Peripheral plasma progesterone levels in pigs during the oestrus cycle. J. Reprod., Fert., 20, 443-449.

Swanson L. V., Hafs H. D., I97I. LH and prolactin in blood serum from estrus to ovulation in Holstein heifers. J. Anim. Sci., 33, I038-ro4I.

Symons A. M., Cunningham N. F., Saba N., I973. Oestrogen-induced LH surges in the anoestrous and cyclic ewe. J. Reprod. Fert., 35, 569-57I.

Symons A. M., Cunningham N. F., Saba N., 1974. The gonadotrophic-hormone response of anoestrous and cyclic ewes to synthetic Juteinizing hormone releasing hormone. J. Reprod. Fert., 39, I I-2 I.

Terqui M., Dray Ii, Cotta J., I973. Variations de la concentration de l'œstradiol-r7 $\beta$ dans le sang périphérique de la Brebis au cours du cycle œestral. C. R. Acad. Sc., Paris, Ser. D, 277, I795-I798.

Thimonier J., Cognie Y., ig7r. Accélération des mises-bas et conduite d'élevage chez les ovins. Bull. Tech. Inform. Minist. Agric., 257, 187-196.

Thimonier J., Pelletier J., I97i. Différences génétiques dans la décharge ovulante (LH) chez les brebis de race Ile-de-France : relations avec le nombre d'ovulations. Ann. Biol. anim. Bioch. Biophys., 11, $559-567$.

Thimonier J., Terqui M., Pelletrer J., I974. Plasma estradiol and progesterone levels and pituitary responsiveness to LRH in the ewe. 4th int. Cong. Horm. Steroids, Mexico, J. Steroid Biochem., 5, 338 .

Thorburn G. D., Bassett J. M., Smith I. D., i969. Progesterone concentrations in the peripheral plasma of sheep during the oestrous cycle. J. Endocr., 45, 459-469.

Wettemann R. P., Hafs H. D., I973. Pituitary and gonadal hormones associated with fertile and non fertile insemination at synchronized and control estrus. J. Anim. Sci., 36, 7I6-721.

Wheatley I. S., Radford H. M., I969. Luteinizing hormone secretion during the oestrous cycle of the ewe as determined by radioimmunoassay. J. Reprod. Fert., 19, $2 \mathrm{II}-2 \mathrm{I} 4$.

White W. F., Hedlung M. T., Rippel R. H., Arnold W., Flouret G. R., 1973. Chemical and biological properties of gonadotropin releasing hormone synthetized by the solid-phase method. Endocrinology, 93, 96- I08.

Yen S. S. C., VAndenberg G., Rebars R., Ehara Y., 1972. Variation of pituitary responsiveness to synthetic LRF during different phases of the menstrual cycle. J. Clin. Endocr. Metab., 35, $931-934$. 
Zolman J., Convey E. M., Britt J. H., Hafs H. D., 1973. Release of bovine luteinizing hormone by purified porcine and synthetic gonadotropin releasing hormone. Proc. Soc. exp. Biol. Med., 142, I89-193.

Zolman J., Convey E. M., Britt J. H., 1974. Relationship between the luteinizing hormone response to gonadotropin releasing hormone and endogenous steroids. J. Anim. Sci., 39, 355-359. 